\title{
Teachers' Time Management and the Performance of Students: A Comparison of Government and Private Schools of Hyderabad, Sindh, Pakistan
}

\author{
Zafarullah Sahito ${ }^{1, *}$ Mumtaz Khawaja ${ }^{2}$, Uzma Murad Panhwar ${ }^{3}$, Abida Siddiqui ${ }^{3}$ \& Humera Saeed $^{4}$ \\ ${ }^{1}$ School of Applied Educational Science and Teacher Education, Philosophical Faculty, University of Eastern \\ Finland, Joensuu \& Department of Education, Sukkur IBA, Sindh, Pakistan \\ ${ }^{2}$ Department of Education, Faculty of Education, University of Sindh, Elsa Kazi campus, Hyderabad, Pakistan \\ ${ }^{3}$ Department of Educational Management and Supervision, Faculty of Education, University of Sindh, Elsa Kazi \\ Campus, Hyderabad, Pakistan \\ ${ }^{4}$ Literacy and Education Department, Government of Sindh, Pakistan \\ *Correspondence: School of Applied Educational Science and Teacher Education, Philosophical Faculty, University \\ of Eastern Finland, Joensuu \& Department of Education, Sukkur IBA, Sindh, Pakistan. E-mail: \\ Zafarullah.sahito@gmail.com
}

Received: October 18, 2016

Accepted: November 5, 2016 Online Published: December 12, 2016

doi:10.5430/wje.v6n6p42

URL: http://dx.doi.org/10.5430/wje.v6n6p42

\begin{abstract}
Time is a precious and so important thing as well as the blessing of the Creator in the world. It is the time which makes, changes, creates, decorates, maintains, develops, strengthens, and successes the present and secures the future of the people and the nations. Time considers a great cure and care for any unethical, unsocial and invaluable matter and event. Time settles each and every hurdle and difficulty of any system and nation with its pace, speed and direction. If time is managed properly according to needs and the requirements of the matters and phenomenon of any nation then no one can stop any nation to be a developed and successful.

This research paper aims to explore and investigate the importance and see the impact of Time Management in the professional life of teachers and the performance of the students of Primary schools in the districts of Hyderabad. In these connections 30 primary teachers were constituted as the sample of the study. Interviews were conducted on the Primary school Teachers of Government / Public and Private School Teachers in order to collect the data about Time Management of teachers and the Performance of the students. A qualitative research design was used to collect data from the sample.
\end{abstract}

Keywords: time management; primary school teachers; performance; public \& private schools

\section{Introduction}

Time is precious and important which never waits for any one. Time is the second name of care and cure that solves as well as resolves the difficult and impossible problems and matters of the people and the nations of the world. The nations who took care about time and made their policies and planning according the needs and the requirements of their people and the competition of nations at global level, they became as the developed nations and they also acquired, saved, popularized and made their strong identification among the countries of the world. Because the wasted time cannot be replaced with increasing demands at workplace and home. The pace of life is becoming fast that's why people are trying to do things faster to contract time expenditure as eat faster, less sleep and make phone calls while having lunch and working (Garhammer, 2002). It shows the perception of time, its importance and management in organizational contexts (Palmer \& Schoorman, 1999) that leads towards the experience of time pressure among employees (Major et al., 2002; Teuchmann et al., 1999; Jackson \& Martin, 1996). In this regard many authors have discussed the need of time management for better incorporating time in theoretical models and 
research designs (Wright, 2002; Ancona et al., 2001; George \& Jones, 2000;) as people can manage their time and improved their efforts (Macan, 1994) to make their working environment supportive.

Time management means the maximum use of time for the productivity and achievement. It concerns with the management of schedules of work with advanced planning, organizing and implementation in order to achieve the aims and objectives of their and the organizations. Time is probably the most valuable asset available to people and organizations to understand the process of the management of time and the contribution of one's to the success of personal and professional lives. However, as any other asset it may be wasted if it is not valued. Time management concerns with the discovery and the application of the most efficient methods of completing assignments of any length with in the required time with quality but do not waste the time. It is human nature to waste time according to their interests and easiness in order to deviate from the work and responsibility in any organization. But on the other side some people have good time management skills to develop their habits to get success in their life. But others have developed poor habits related to time which are not proclaimed or admitted by the people as weaknesses.

\subsection{Role or Research Definition}

Time management is a process of managing the time according to the need and requirement of work and activities in order to utilize, save and do not waste the time for an effective organizational progress and success. Time management includes the construction and implementation of time table, distribution of subjects, total number of periods taken by teachers, lesson planning, regularity and punctuality of teachers in school and class, advance planning of class activities, counseling and guidance of teachers, time allocation to students individually, organization and preparation of co-curricular activities for students.

\subsection{Statement of the Problem}

This study is designed to explore and investigate the habits, routines and schedules of teachers that how they use to plan, design, manage, implement, evaluate and achieve the aims and objectives of their teaching learning process. In this regard the time management of the activities of primary teachers is focused to collect the data and analyze it to get proper, accurate and authentic results about the relationship of teachers' time management and its impact on students' performance in government and private schools. As the private schools are known and famous as the symbol of success and achievement in the minds and hearts of the people in Sindh province of Pakistan.

\section{Literature Review}

Time management is a misleading that cannot be managed, because it is an inaccessible factor that can be viewed as a monitoring and controlling the time (Eilam \& Aharon, 2003). There is no permanent and accurate definition of time management available in past literature and studies. Although many authors referred and supported that it is the process of determining needs, setting goals to achieve determined needs, prioritising and planning the tasks required to achieve the settled goals (Lakein, 1973). It is also referred as techniques for managing time (Davis, 2000; Jex \& Elacqua, 1999; Mudrack, 1997; Macan, 1996, 1994; Macan et al., 1990;) as technique for effective use of time to accomplish the tasks required (Orpen, 1994; Slaven \& Totterdell, 1993; Woolfolk \& Woolfolk, 1986) for planning and allocating (Francis-Smythe \& Robertson, 1999a; Burt \& Kemp, 1994) as to be structured and purposive (Sabelis, 2001; Strongman \& Burt, 2000; Vodanovich \& Seib, 1997; Bond \& Feather, 1988) to get insight to use time efficiently to pursue the activities (King et al.,1986) and practices to maximize intellectual productivity (Britton \& Tesser,1991).

Time management is straight forwardly defined as the management of time in order to make the most out of it (David, 1999), it refers to all of the practices that individuals follow to make better use of their time (Allen, 2001) and narrowly refers to the principles and systems that individuals use to make conscious decisions about the activities that occupy their time. Time management is an application of self-regulation processes (Griffiths, 2003), coping behaviour of risk populations (King et al., 1986), self-regulation strategies to discuss plans and their efficiency (Eilam \& Aharon, 2003), to use the procedures that are designed to help the individuals to achieve their goals (Hall \& Hursch, 1982) by assessing the activities to prioritise the plans (Kaufman-Scarborough \& Lindquist, 1999) to facilitate the productivity and alleviate stress (Lay \& Schouwenburg, 1993).

The time management behaviours were found positively related to perceived control of time, job satisfaction, health, and negatively to stress. Time management training helps the teachers to enhance their time management skills, but 
not support directly and automatically to the performance as to become better (Claessens, Eerde, Rutte, \& Roe, 2007). In First Things First, Stephen R. Covey and his co-authors offered a categorization scheme for the hundreds of time management approaches that they reviewed:

- First generation: reminders (based on clocks and watches, but with computer implementation possible) can be used to alert of the time when a task is to be done.

- Second generation: planning and preparation (based on calendar and appointment books) includes setting goals.

- Third generation: planning, prioritizing, controlling (using a personal organizer, other paper-based objects, or computer- or PDA-based systems) activities on a daily basis. This approach implies spending some time in clarifying values and priorities.

- Fourth generation: being efficient and proactive (using any tools above) places goals and roles as the controlling element of the system and favors importance over urgency (Covey, 1994).

As we know that the schools are the social institutions of the society which play a vital role to meet and try to achieve the aims and objectives of the society. These aims and objectives can be achieved only through education and schools are the best and proper places to acquire and propagate education. If education is considered as the human body then curriculum is its blood which circulates in it. With out blood no body can works so with out curriculum no education can achieve its targets. Curriculum consists on knowledge and knowledge is the product of subject matter which is taught by teachers at each level in schools. If the teacher wants to teach the content properly and efficiently according to the needs, requirements and the interests of the students then it must be done through good and advanced planning, procedure, regularity and punctuality, time schedule and effective procedure of evaluation. However, above all items are possible to implement through time management of teachers in and out side of schools. Because a teacher is the helper, opportunities provider, implementer, designer of activities, knowledge share outer, problem solver, career counselor and time manager.

\section{Research Design, Data Collection Methods and Procedures}

The researcher used the qualitative research design to collect data from the respondents. In this connection an interview protocols was designed to collect the data from the teachers of primary schools, as the study focuses on the qualitative data through interviews as to collect detailed views from the recruited participants (Creswell, 2009, pp.18). The interview protocol was discussed with the panel of 10 experts of the field (5 authors and 5 other experts) for validity and reliability check then the piloting was done to see the results either the tool is capable to collect proper required data or not. Finally, after suggested and observed things the changes were made and the tool was finalized to collect data.

All Government and Private primary schools of Hyderabad district were constituted as the population of the study. This study is delimited ranging the students of class five of the Primary schools of the city. After delimitation of the study the purposive sampling techniques were used to select the sample of the study from schools and teachers, to recruit the appropriate sample for the study. As in some cases, the researcher might be study a single individual or a single site and in other cases, the number may be several, ranging from 1 or 2 to 30 or 40 (Creswell, 2012, p. 209). So in this study the researcher went to recruit 30 teachers (15 from Government / Public and 15 from Private schools). So this can be said that this is a case of 10 schools of Hyderabad city of Sindh, province of Pakistan, 5 Government / Public and 5 Private (3 teachers from each school). Furthermore, the data was collected personally with the help of co- authors, some friends, colleagues and trainees. During interviews the views and the strong statements were recorded as first hand information and the primary data was recorded and written in the interview protocol proforma. All results of collected data were compared to each other under different themes for better and easy understanding, while the data also discussed about the facts and figures with their causes and reasons. This research paper will be proved a suitable, reliable and authentic source of data and facts about time management of teachers and performance of students in this area where no more studies have been done about time management and the performance of students.

\subsection{Research Questions}

Q.1: What is the perception of teachers about time management to fulfill their duties and responsibilities in their 
profession?

Q.2: How teachers manage their time to fulfill all assignments at their schools?

Q.3: How time management of teachers' impact on the student performance?

\section{Results}

Q.1: What is the perception of teachers about time management to fulfill their duties and responsibilities in their profession?

The perception of the teachers about time management is to come and leave the school on time and during working hours fully concentrates on the assignments given by the school management and try to complete them before or by the deadlines [Majority of Private School Teachers (PSTs)]. Work may be at school and home till the completion of assignments, but sometimes the assignments could not be completed in due time [Majority of Government/Public School Teachers (GPSTS)].

Q.2: How teachers manage their time to fulfill all assignments at their schools?

Through wise planning, careful designing, proper implementation and hardworking to keep things on priority basis as the assignments can be fulfilled and the desired results can be achieved through different activities such as regularity and punctuality of teachers, prepare class / lecture schedule in advance, plan the lesson / prepare the topic in advance for coming class, design activities in advance to teach any topic in class, try to get students' active participation in classroom activities, do review and repetition of lecture before finishing the topic (majority of PSTs $\&$ GPSTs). While, construction and implementation of time table in advance, distribution of subjects on expertise basis, period wise system (means separate period for separate subject), each subject taught separately by different teacher, come / stand five to ten minutes before at the front of classroom to take period, advance planning to use audio visual aids during teaching learning process, use to give time to students individually during class, proper and separate time allocation for counseling and guidance of students, plan, prepare and organize co-curricular activities for students (majority of PSTS).

Q.3: How time management of teachers' impact on the student performance?

Proper time allocation and the management of different things, works and activities such as regularity and punctuality; advanced preparation of different schedules, lesson plans and activities (majority of PSTs \& GPSTs).; acquiring students' active participation; review and repetition of lectures; dealing students individually; teaching the different subjects by subject specialists; readiness and high level of willingness of teachers; advance planning of using multidimensional things to teach depending on students centered teaching learning process; separate time allocation for counseling and guidance of students; plan, prepare and organize curricular and co-curricular activities for students physical and spiritual developments; dedication and commitment of teachers; support of administration; availability of resource or resource development; proper and authentic feedback system for teachers and students impact positively on the time management skills of teachers which is positively and directly connected with the performance of students (majority of PSTS).

The total difference in the percentages of activities levels of teachers between GPSTs and PSTs is (63.80) given in the general table, collected from the comparative activities in table 1. The details of tables' shows the progress of PSTs is much better than the GPSTs, only due to the proper system managed by school administration, management of time, proper check and balance and the ownership of the heads and staff. 
Table 1. Comparison of the Views of GPSTs \& PSTs about Different Items

\begin{tabular}{|c|c|c|c|}
\hline S\# & $\begin{array}{l}\text { Themes explored from } \\
\text { the interview of teachers }\end{array}$ & Views of GPSTs & Views of PSTs \\
\hline 1 & Time table & $\begin{array}{l}\text { No time table constructed properly by the } 70 \% \\
\text { heads of Government / Public Schools (GPSs) } \\
\text { and only verbal distribution of classes is done } \\
\text { by them }\end{array}$ & $\begin{array}{l}80 \% \text { heads of Public Schools (PSs) do construct } \\
\text { their own time table properly in advance to run } \\
\text { their institutions smoothly }\end{array}$ \\
\hline 2 & $\begin{array}{l}\text { Distribution of the } \\
\text { subjects }\end{array}$ & $\begin{array}{l}\text { No provision of the advance distribution of the } \\
\text { subjects is available in the time table said by } \\
62 \% \text { heads of GPSs }\end{array}$ & $\begin{array}{l}84 \% \text { PSs give provision of the advance } \\
\text { distribution of subjects among teachers in order } \\
\text { to teach an appropriate subject by the concerned } \\
\text { teacher }\end{array}$ \\
\hline 3 & Period wise system & $\begin{array}{l}\text { There is no provision of the distribution of the } \\
\text { time period / limit in the time table given by } \\
80 \% \text { GPSs }\end{array}$ & $\begin{array}{l}90 \% \text { PSs appreciate the period wise system that } \\
\text { different teacher can teach different subjects to } \\
\text { students in order to share and enhance more } \\
\text { skills and knowledge with students }\end{array}$ \\
\hline 4 & Subject specialists & $\begin{array}{l}\text { There is no provision of different teachers to } \\
\text { teach different subjects. } 90 \% \text { of teachers of } \\
\text { GPSs do not have the above same system }\end{array}$ & $\begin{array}{l}95 \% \text { PSs have the system of periods and } \\
\text { different teachers use to teach different subjects }\end{array}$ \\
\hline 5 & $\begin{array}{l}\text { Regularity } \\
\text { punctuality }\end{array}$ & $\begin{array}{l}\text { The only } 16 \% \text { GPSTs are regular and punctual, } \\
53 \% \text { are regular and the rest of the teachers are } \\
\text { not regular and punctual }\end{array}$ & $\begin{array}{l}92 \% \text { PSTs are most regular and punctual and the } \\
\text { rest of the teachers are regular }\end{array}$ \\
\hline 6 & Readiness to take class & $\begin{array}{l}\text { Only } 14 \% \text { GPSTs use to come to class at right } \\
\text { time. }\end{array}$ & $\begin{array}{l}74 \% \text { PSTs use to come and stand at the front of } \\
\text { the class five / ten minutes before the class and } \\
\text { rest of PSTs come to class at right due time }\end{array}$ \\
\hline 7 & $\begin{array}{l}\text { Advance preparation for } \\
\text { class schedules }\end{array}$ & $\begin{array}{l}10 \% \text { GPSTs use to prepare classes / lecture } \\
\text { schedules in advance }\end{array}$ & $\begin{array}{l}91 \% \text { PSTs use to prepare classes / lecture } \\
\text { schedules in advance }\end{array}$ \\
\hline 8 & $\begin{array}{l}\text { Advance preparation of } \\
\text { lesson plans }\end{array}$ & $\begin{array}{l}\text { Only } 13 \% \text { GPSTs use to plan and prepare } \\
\text { lessons / topics in advance }\end{array}$ & $\begin{array}{l}89 \% \text { PSTs use to plan and prepare lessons } \\
\text { topics in advance and submit them to principal } \\
\text { office }\end{array}$ \\
\hline 9 & $\begin{array}{l}\text { Planning and designing } \\
\text { of activities }\end{array}$ & $\begin{array}{l}\text { Only } 11 \% \text { GPSTs use to plan, design and } \\
\text { prepare the activities in advance to teach any } \\
\text { lesson/topic in the class }\end{array}$ & $\begin{array}{l}89 \% \text { PSTs use to plan, design and prepare the } \\
\text { activities in advance to teach any lesson / topic in } \\
\text { the class }\end{array}$ \\
\hline 10 & $\begin{array}{l}\text { Planning and usage of } \\
\text { aids }\end{array}$ & $\begin{array}{l}\text { Only } 11 \% \text { GPSTs use to plan about A.V.Aids in } \\
\text { advance in order to use during teaching learning } \\
\text { process to teach any lesson / topic in the class }\end{array}$ & $\begin{array}{l}78 \% \text { PSTs use to plan about A.V.Aids in } \\
\text { advance in order to use during teaching learning } \\
\text { process to teach any lesson / topic in the class }\end{array}$ \\
\hline 11 & $\begin{array}{l}\text { Acquiring students } \\
\text { participation in class }\end{array}$ & $\begin{array}{l}18 \% \text { GPSTs try to get the maximum } \\
\text { participation of students in their class activities }\end{array}$ & $\begin{array}{l}72 \% \text { PSTs try to get the maximum participation } \\
\text { of students in their class activities }\end{array}$ \\
\hline 12 & $\begin{array}{l}\text { Review and repetition of } \\
\text { lessons and topics }\end{array}$ & $\begin{array}{l}16 \% \text { GPSTs use to do repetition of their lecture } \\
\text { before finishing the topic }\end{array}$ & $\begin{array}{l}64 \% \text { PSTs use to do repetition of their lecture } \\
\text { before finishing the topic }\end{array}$ \\
\hline 13 & $\begin{array}{l}\text { Time allocation and } \\
\text { utilization }\end{array}$ & $\begin{array}{l}\text { Only } 10 \% \text { GPSTs use to give time to students } \\
\text { separately and individually during class }\end{array}$ & $\begin{array}{l}58 \% \text { PSTs use to give time to students separately } \\
\text { and individually during class }\end{array}$ \\
\hline 14 & $\begin{array}{l}\text { Counseling } \\
\text { guidance hours }\end{array}$ & $\begin{array}{l}12 \% \text { GPSTs use to do counseling and guidance } \\
\text { of their students properly and effectively }\end{array}$ & $\begin{array}{l}68 \% \text { PSTs use to do counseling and guidance of } \\
\text { their students properly and effectively }\end{array}$ \\
\hline 15 & $\begin{array}{l}\text { Organization of } \\
\text { co-curricular activities }\end{array}$ & $\begin{array}{l}\text { Only } 4 \% \text { GPSTs use to organize and do advance } \\
\text { preparation of co-curricular activities for their } \\
\text { students. }\end{array}$ & $\begin{array}{l}66 \% \text { PSTs use to organize and do advance } \\
\text { preparation of co-curricular activities for their } \\
\text { students }\end{array}$ \\
\hline
\end{tabular}


Table 2. Comparison of Percentages of Work and Time Management Activities

\begin{tabular}{lll}
\hline S. No & Items & Total Average Percentage \\
\hline 1 & Government/Public School Teachers (GPSTs) & 15.54 \\
2 & Public School Teachers (PSTs) & 79.34 \\
\hline
\end{tabular}

\section{Discussion and Conclusion}

On the basis of the collected data we conclude that the Public Primary School Teachers do not aware about the good system of planning of their lessons / lectures and they have no environment to learn from their senior colleagues. Some other factors also effect negatively on the performance of the teachers, i.e. mismanagement of heads of schools, improper time management, lack of training, etc. but on the other side private primary school teachers do good planning in advance due to good administrative system and accent ability teacher. Trainings can bring positive change in the attitude and behaviour of teachers to maintain and manage their time skills, as the training programs on time management and outcomes with respect to the effectiveness of time management training were found effective and after their continuous evaluation it was also found that the participants were remained engage in time management behaviours more frequently after attending training program (Green \& Skinner, 2005; King et al., 1986; Macan, 1994; Slaven \& Totterdell, 1993; Van Eerde, 2003) and there is a positive relation between time management training and performance (Hall \& Hursch, 1982; King et al., 1986; Orpen, 1994).

Impact of teacher time management is directly proportioned with the performance of students, teachers of public primary schools do planning actively and intelligently then they may be able in future to produce more intelligent minds for the future development of the nation. The significant relationship between teachers' time management and students' academic performance was found. The level of teachers' time management and academic performance was moderate, that's why it was recommended that teachers should improve their time management skills through consciousness about controlling their time (Kayode, \& Ayodele, 2015). Because teachers complaint of lack of time to do certain things (Ekundayo, Konwea \& Yusuf, 2010). The resources that affect students' academic performance were grossly inadequate and one of these resources is time management that has significant impacts on students' academic performance though a little or no investigation has been carried out (Akinwonmi, 2006). The class size (Lindahl, 2005), teachers' qualification (Rivkin, Hanushek \& Kain, 2005), teachers' length of service (Demir, 2009) and teachers attitude (Adesoji, 1999) affects students' academic performance. But effective utilization of teachers' time management (Ayodele \& Oyewole, 2012) directly impacts students' academic performance (Ayodele \& Ige, 2012; Achibong \& Nja, 2011; Akinfolarin, 2008; Ayodele \& Abiodun, 2008; Adesola, 2005; Ahievbolaria, 2005)

\section{Suggestions}

- Teachers should be given some sought of training about the management of time.

- Teachers should be insisted to plan their lessons in advance / before the delivering of their lesson / lecture.

- Teachers planning should be focused and bases on the distribution of time according the requirement of time of any activities.

- Competition and appreciation method should be used to motivate the teachers to plan their lessons to save the time.

- Teachers should keep focus on the needs, sharing the knowledge, issues and problems, active participation of students in different activities and confidence development of the students.

\section{References}

Adesoji, F. A. (1999). Mock examination results and students gender as correlates of performances in the school certificate examinations in Mathematics. African Journal of Educational Research, 5(1), 101-107.

Adesola, A. A. (2005). Resources provision and utilization, Mathematics ability and learning environment as prediction of learning outcomes in undergraduate practical Geography. Unpublished Ph. D Thesis, University of Ibadan, Ibadan.

Ahievboloria, J. E. V. (2005). A comparative study of manpower and physical facilities in tertiary institutions in 
Delta State. Unpublished M. Ed. Dissertation. Delta State University, Abraka, Nigeria.

Akinfolarin, C. A. (2008). Resources utilization in vocational and technical education in College of Education, South West Nigeria. Unpublished Ph.D Thesis, University of Ado-Ekiti, Ado-Ekiti, Nigeria.

Akinwonmi, O. (2006). Differential distribution and utilization of educational resources and academic performance in secondary schools in Ogun State. Unpublished Ph.D Thesis, Olabisi Onabanjo Univeristy, Ago- Iwoye, Nigeria.

Allen, David. (2001). Getting things Done: the Art of Stress-Free Productivity. New York: Viking.

Ancona, D.G., Goodman, P.S., Lawrence, B.S., \& Tushman, M.L. (2001). Time: a new research lens. Academy of Management Review, 26, 645-63.

Archibong, I. A., \& Nja, M. E. (2011). Towards Improved Teaching Effectiveness in Nigerian Public Universities: Instrument Design and Validation. Higher Education Studies, 1(2), 78-91. http://dx.doi.org/10.5539/hes.v1n2p78

Ayodele, J. B., \& Abiodun, O. O. (2008). The issues of quality assurance in Nigerian universities. Pp. 142-149. In Babalola, J. B. et. al. (Eds.), Towards Quality in African Higher Education. Higher Education Research and Policy Network / The Postgraduate School, University of Ibadan, Ibadan.

Ayodele, J. B., \& Ige, M. A. (2012). Teachers' utilization as correlate of students' academic performance in senior secondary schools in Ondo State, Nigeria. European Journal of Educational Studies, 4(2), 282-287.

Ayodele, J. B. \& Oyewole, B. K. (2012). Repositioning the teaching profession to meet developmental challenges in Nigeria. Mediterranean Journal of Social Sciences, 3(3), 47-51. http://dx.doi.org/10.5901/mjss.2012.v3n3p47

Bond, M., \& Feather, N. (1988). Some correlates of structure and purpose in the use of time. Journal of Personality and Social Psychology, 55, 321-329. http://dx.doi.org/10.1037/0022-3514.55.2.321

Britton, B.K., \& Tesser, A. (1991). Effects of time-management practices on college grades. Journal of Educational Psychology, 83, 405-410. http://doi.apa.org/journals/edu/83/3/405.pdf

Burt, C.D.B., \& Kemp, S. (1994). Construction of activity duration and time management potential. Applied Cognitive Psychology, 8, 155-68. http://dx.doi.org/10.1002/acp.2350080206

Claessens, B. J.C., Eerde, W. V., Rutte, C. G., \& Roe, R. A. (2007). A review of the time management literature. Personnel Review, Emerald Group Publishing Limited, 36(2), 255-276. http://dx.doi.org/10.1108/00483480710726136

Covey, S. (1994). First Things First. ISBN 0-684-80203-1

Creswell, J. W. (2012). Educational research: planning, conducting, and evaluating quantitative and qualitative research, 4th(ed.). Pearson Education, Inc., Boston, USA.

Creswell, J.W. (2009). Research design: Qualitative, quantitative and mixed methods approaches, $3^{\text {rd }}$ (ed.). London, England: Sage Publications.

David A. S. (1999). The Concise Dictionary of Business Management, Page 175. Taylor \& Francis Group, ISBN 9780415188678,

Davis, M.A. (2000). "Time and the nursing home assistant: relations among time management, perceived control over time, and work-related outcomes", paper presented at the Academy of Management, Toronto.

Demir, C. E. (2009). Factors influencing the academic achievement of the Turkish urban poor. International Journal of Educational Development, 29, 17-29. http://dx.doi.org/10.1016/j.ijedudev.2008.03.003

Eilam, B., \& Aharon, I. (2003). Students planning in the process of self-regulated learning. Contemporary Educational Psychology, 28, 304-34. http://dx.doi.org/10.1016/S0361- 476X (02)00042-5

Ekundayo, H.T., Konwea, P.E., \& Yusuf, M. A. (2010). Towards effective time management among lecturers in Nigerian Universities. Journal of Emerging Trends in Educational Research and Policy Studies, 1(1), 22-24.

Francis-Smythe, J.A., \& Robertson, I.T. (1999a). On the relationship between time management and time estimation. British Journal of Psychology, 90, 333-47.

Garhammer, M. (2002). Pace of Life and Enjoyment of Life. Journal of Happiness Studies, 3, 217-256. http://dx.doi.org/10.1023/A: 1020676100938 
George, J.M. \& Jones, G.R. (2000). The role of time in theory and theory building. Journal of Management, 26(4), 657-684. http://dx.doi.org/10.1177/014920630002600404

Green, P., \& Skinner, D. (2005). Does time management training work: an evaluation. International Journal of Training and Development, 9, 124-39. http://dx.doi.org/10.1111/j.1468- 2419.2005.00226.x

Griffiths, R.F. (2003). "Time management in telework and other autonomous work environments", Dissertation Abstract International: Section B: The Sciences and Engineering, 64, p. 5B.

Hall, B.L., \& Hursch, D.E. (1982). An evaluation of the effects of a time management training program on work efficacy. Journal of Organizational Behaviour Management, 3, 73-98. http://dx.doi.org/10.1300/J075v03n04_08

Jackson, P.R., \& Martin, R. (1996). Impact of just-in-time on job content, employee attitudes and well-being: a longitudinal study. Ergonomics, 39(1), 1-16. http://dx.doi.org/10.1080/00140139608964429

Jex, J.M., \& Elacqua, T.C. (1999). Time management as a moderator of relations between stressors and employee strain. Work \& Stress, 13, 182-91. http://dx.doi.org/10.1080/026783799296138

Kaufman-Scarborough, C., \& Lindquist, J.D. (1999). Time management and polychronicity: comparisons, contrasts, and insights for the workplace. Journal of Managerial Psychology, 14, 288-312. http://dx.doi.org/10.1108/02683949910263819

Kayode, G. M., \& Ayodele, J. B. (2015). Impacts of Teachers' Time Management on Secondary School Students' Academic Performance in Ekiti State, Nigeria. International Journal of Secondary Education, 3(1), 1-7. http://dx.doi.org/10.11648/j.ijsedu.20150301.11

King, A.C., Winett, R.A., \& Lovett, S.B. (1986). Enhancing coping behaviours in at-risk populations: the effects of time-management instruction and social support in women from dual-earner families. Behaviour Therapy, 17, 57-66.

Lakein, A. (1973). How to Get Control of your Time and Life, Nal Penguin Inc., New York, NY.

Lay, C.H., \& Schouwenburg, H.C. (1993). Trait procrastination, time management, and academic behavior. Journal of Social Behavior and Personality, 8, 647-62.

Lindahl, M. (2005). Home versus school learning: A new approach to estimating the effect of class size on achievement. Scandinavian Journal of Economics, 107(2), 375-394.

Macan, T.H. (1994). Time management: test of a process model. Journal of Applied Psychology, 79, 381-391. http://dx.doi.org/10.1037/0021-9010.79.3.381

Macan, T.H. (1996). Time-management training: effects on time behaviours, attitudes, and job performance. The Journal of Psychology, 130, 229-36. http://dx.doi.org/10.1080/00223980.1996.9915004

Macan, T.H., Shahani, C., Dipboye, R.L., \& Philips, A.P. (1990). College students' time management: correlations with academic performance and stress. Journal of Educational Psychology, 82, 760-768. http://dx.doi.org/10.1037//0022-0663.82.4.760

Major, V.S., Klein, K.J., \& Ehrhart, M.G. (2002). Work time, work interference with family, and psychological distress. Journal of Applied Psychology, 87, 427-36. http://dx.doi.org/10.1037//0021-9010.87.3.427

Mudrack, P. (1997). The structure of perceptions of time. Educational and Psychological Measurement, 57, 222-240. http://dx.doi.org/10.1177/0013164497057002003

Orpen, C. (1994). The effect of time-management training on employee attitudes and behaviour: a field experiment. The Journal of Psychology, 128, 393-396. http://dx.doi.org/10.1080/00223980.1994.9712743

Palmer, D.K., \& Schoorman, F. (1999). Unpackaging the multiple aspects of time in polychronicity. Journal of Managerial Psychology, 14(3-4), 323-344. http://dx.doi.org/10.1108/02683949910263918

Rivkin, S. G., Hanushek, E. A., \& Kain, J, F. (2005). Teachers, schools and academic achievement. Econometrica, 73(2), 417- 458. http://www.jstor.org/stable/3598793

Sabelis, I. (2001). Time management: paradoxes and patterns. Time \& Society, 10, 387- 400. http://tas.sagepub.com/content/10/2-3/387

Slaven, G., \& Totterdell, P. (1993). Time management training: does it transfer to the workplace? Journal of Managerial Psychology, 8, 20-28. http://dx.doi.org/10.1108/02683949310024432 
Strongman, K.T., \& Burt, C.D.B. (2000). Taking breaks from work: an exploratory inquiry. Journal of Psychology, 134, 229-242. http://dx.doi.org/10.1080/00223980009600864

Teuchmann, K., Totterdell, P., \& Parker, S.K. (1999). Rushed, unhappy, and drained: an experience sampling study of relations between time pressure, perceived control, mood, and emotional exhaustion in a group of accountants. Journal of Occupational Health Psychology, 4(1), 37-54.

Van Eerde, W. (2003). Procrastination at work and time management training. Journal of Psychology, 137, 421-434. http://dx.doi.org/10.1080/00223980309600625

Vodanovich, S.J., \& Seib, H.M. (1997). Relationship between time structure and procrastination. Psychological Reports, 80, 211-215. http://dx.doi.org/10.2466/pr0.1997.80.1.211

Woolfolk, A.E., \& Woolfolk, R.L. (1986). Time management: an experimental investigation. Journal of School Psychology, 24, 267-75. http://dx.doi.org/10.1016/0022- 4405(86)90059-2

Wright, T.A. (2002). Dialogue: the importance of time in organizational research. Academy of Management Journal, $45,343-5$. 